being constructed by Sverdrup and Parcel of St. Louis, Missouri, which is the largest solar energy plant in the worid. With some $5,000 \mathrm{~m}^{2}$ of collectors, the plant in the system supplies $70 \%$ of the total heat load by solar energy. The price tag has a pay back of 20 years; with the replacement of parts included in the cost-analysis. Sverdrup and Parcel claim that the system should be usable for a total of 30 to 35 years. Perhaps!

- The second, a more modest plant, is being developed in Riyadh by Safretes of France. With $6,000 \mathrm{~m}^{2}$ of collectors, the system is designed to produce an output of $45 \mathrm{~kW}$ of power. - A similar third plant is being developed by SOTEC of Switzerland for King Abdulaziz University in Jed- dah. The project is designed to familiarise students with unconventional seawater desalination method based on solar energy. A solar collector farm will be linked to a multistage flush evaporator for the production of fresh water.

- The fourth project is perhaps the most interesting for it is concerned with the supply of power to small villages in remote places. Normally such villages are supplied by local power stations using diesel engines of sizes varying between $200-2,000 \mathrm{~kW}$. The Kingdom's electricity corporation has decided to replace these stations by thermodynamic conversion solar stations with flat plate collectors. Although it is recognised that solar cells are expensive and any device using them will ordinarily be prohibitive, all considerations of cost have been displaced by the desire to solve the "problems" of the people living in desert areas. The prototype system, which will be used as a research and development centre for solar power plants, is to be designed by Safretes.

It is debatable whether, in the long run, anything lasting can be achieved by such conspicuous projects and flow of capital. The Saudis are quite content with buying off-the-shelf technology-which makes nonsense of all the talk of future self-sufficiency. Not everyone is impressed, however. As one prominent Saudi scientist said at Soltech, "Its all very well to bring this equipment home and play around with it. But don't call that research".
WhEN Adam and Eve were driven out of the Garden of Eden, they were told: "By the sweat of thy face shalt thou eat bread", the implication was that they would have to work very hard to obtain enough food to survive. This text from the book of Genesis has convinced most people that the life of early man was one of endless toil. They also assume that the same is true for the members of tribes living today whose way of life is usually considered to be primitive.

That this view is generally false is well known to anthropologists, and it is interesting to see the actual figures for hours worked by different communities. Gerald Leach, in his painstaking report 'Energy and food production' shows that hunter-gathers like the ! Kung bushmen of the Kalahari desert in South Africa spend less than a quarter of the 'working week' gathering food, and much of this is hardly a strenuous activity. They are mainly engaged in a leisurely stroll around the large area-over ten square kilometres a head-within which they can pick up their supplies of wild foods.

This idyllic situation was changed when arable crops were introduced by the first true farmers. Much more food was produced, and settlements of a greater density became possible. The cultivators, particularly at times of planting and harvest, had to do more work. Nevertheless, feeding a family with their own produce was hardly a full time job for subsistence farmers. The men at least had long hours for contemplation and recreation, even if they did some of the harder seasonal jobs like clearing secondary bush after a period of fallow. Even the women only worked in the field intermittently, though their elaborate procedures for preparing food kept them busy (and out of mischief) for long hours. Only when the peasants had to produce more food than they could eat, to sell

\section{Self-sufficiency on one-tenth of an acre}

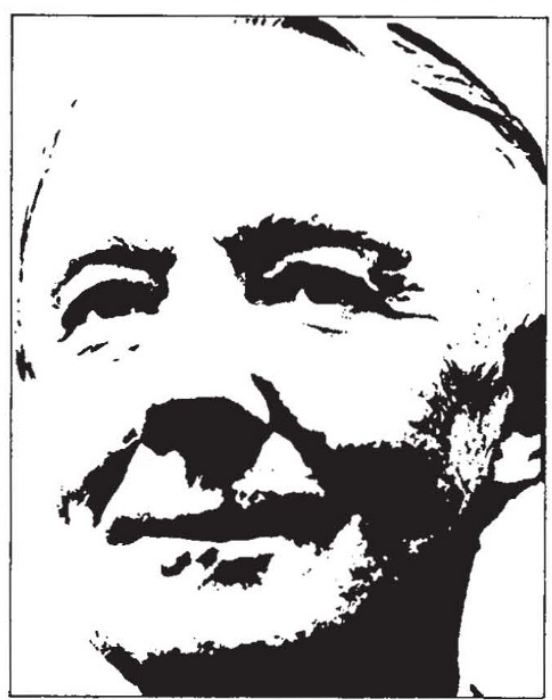

KENNETH MELLANBY

to pay taxes or to buy luxuries, did they begin to work really hard.

Today in most western countries we find substantial numbers of people with the urge to become self sufficient, often as a protest at the rat race of modern civilisation. Some work alone, some in family groups, some in communes. Few succeed, and most seem to demonstrate the truth of the text quoted in my first paragraph. They sweat over their toil, and fail to produce the food they need. This is partly because many lack the necessary training in farming and gardening, and waste much of their effort. But generally failure is the result of trying to do too much. To be really self-sufficient on a few acres of poor ground, when this means not only producing adequate food but also selling produce to provide something approaching an urban standard of living, is not an easy task.

But if they emulate the ! Kung bushmen, who only wished to eat, the situation could be quite different. There should be little difficulty in producing enough food for a healthy diet, though many items we now eat would not be available. If a single man were prepared to obtain three quarters of his food as wheat, he could grow the required amount ( $200 \mathrm{~kg}$ for a yearly ration) on an area of about one twentyfifth of a hectare. Using modern farming techniques this could be planted, fertilised, sprayed and harvested in about half an hour per annum. Even with hand labour, digging with a spade and harvesting with a sickle, one or two weeks of hard work should suffice. $\mathrm{He}$ would not have a complete diet, but if he kept a few hens, growing a few more square metres of corn to feed them, allowed his nanny goat to browse on the roadside verges, and did a bit of hunting gathering for wild produce, he could live quite well and still have as much leisure as the fortunate bushman. Trouble would only arise when he began to hanker after the delights of the civilisation he had abandoned. 